\title{
Serum levels of the chemokine CCL2 are elevated in malignant pleural mesothelioma patients
}

\author{
Takumi Kishimoto ${ }^{1}$, Nobukazu Fujimoto ${ }^{1}$, Takeshi Ebara ${ }^{2}$, Toyonori Omori ${ }^{3}$, Tetsuya Oguri ${ }^{4}$, Akio Niimi ${ }^{4}$, \\ Takako Yokoyama ${ }^{5}$, Munehiro Kato ${ }^{5}$, Ikuji Usami ${ }^{5}$, Masayuki Nishio ${ }^{6}, K_{\text {Kosho Yoshikawa }}^{6}$, Takeshi Tokuyama? \\ Mouka Tamura ${ }^{8}$, Yoshifumi Yokoyama ${ }^{9}$, Ken Tsuboi ${ }^{10}$, Yoichi Matsuo ${ }^{10}$, Jiegou X u $^{11,12}$, Satoru Takahashi ${ }^{13}$, \\ Mohamed Abdelgied ${ }^{12,13,14}$, William T. Alexander ${ }^{12}$, David B. Alexander ${ }^{12^{*}}$ (D) and Hiroyuki Tsuda ${ }^{12}$
}

\begin{abstract}
Background: Malignant pleural mesothelioma (MPM) is a debilitating disease of the pleural cavity. It is primarily associated with previous inhalation of asbestos fibers. These fibers initiate an oxidant coupled inflammatory response. Repeated exposure to asbestos fibers results in a prolonged inflammatory response and cycles of tissue damage and repair. The inflammation-associated cycles of tissue damage and repair are intimately involved in the development of asbestos-associated cancers. Macrophages are a key component of asbestos-associated inflammation and play essential roles in the etiology of a variety of cancers. Macrophages are also a source of C-C motif chemokine ligand 2 (CCL2), and a variety of tumor-types express CCL2. High levels of CCL2 are present in the pleural effusions of mesothelioma patients, however, CCL2 has not been examined in the serum of mesothelioma patients.

Methods: The present study was carried out with 50 MPM patients and 356 subjects who were possibly exposed to asbestos but did not have disease symptoms and 41 healthy volunteers without a history of exposure to asbestos. The levels of CCL2 in the serum of the study participants was determined using ELISA.

Results: Levels of CCL2 were significantly elevated in the serum of patients with advanced MPM.

Conclusions: Our findings are consistent with the premise that the CCL2/CCR2 axis and myeloid-derived cells play an important role in MPM and disease progression. Therapies are being developed that target CCL2/CCR2 and tumor resident myeloid cells, and clinical trials are being pursued that use these therapies as part of the treatment regimen. The results of trials with patients with a similar serum CCL2 pattern as MPM patients will have important implications for the treatment of MPM.
\end{abstract}

Keywords: Asbestos, Cancer, Malignant pleural mesothelioma, CCL2

\section{Background}

A causal association between exposure to at least some types of asbestos and lung carcinomas and malignant pleural mesothelioma (MPM) has been long recognized [1], and in 2012 the WHO/International Agency for Research on Cancer (IARC, Lyon) classified all forms of asbestos (chrysotile, crocidolite, amosite, tremolite, actinolite, and anthophyllite) as carcinogenic to humans

\footnotetext{
* Correspondence: dalexand@phar.nagoya-cu.ac.jp

${ }^{12}$ Nanotoxicology Project Lab, Nagoya City University, 3-1 Tanabedohri, Mizuho-ku, Nagoya 467-8603, Japan

Full list of author information is available at the end of the article
}

[2]. The 2014 updated Helsinki Criteria notes that while the use of asbestos is banned in many industrialized countries, the global production of asbestos remains at over two million metric tons a year, with an estimated 125 million people being exposed to asbestos in the workplace [3]. Furthermore, workers engaged in cleaning debris at sites of natural disasters and workers involved in demolition work may be exposed to asbestos. For example, asbestos-related disease is predicted to be significant in workers engaged in debris cleaning operations after the Great Hanshin Earthquake that occurred in Japan in 1995. Worldwide, asbestos exposure results in

(c) The Author(s). 2019 Open Access This article is distributed under the terms of the Creative Commons Attribution 4.0 International License (http://creativecommons.org/licenses/by/4.0/), which permits unrestricted use, distribution, and 
an estimated 255,000 deaths annually, with a significant fraction (over 30,000 in 2016) of these deaths due to mesothelioma [4]. In Japan, the number of patients that die of MPM is currently 1500 a year (Vital Statistics, Ministry of Health Labour and Welfare, Japan, 2015), and the incidence of MPM is predicted to remain relatively high in the coming years due to past exposure to asbestos.

Macrophages are considered to be essential constituents of many types of solid tumors $[5,6]$, and mesotheliomas are heavily infiltrated by macrophages [7-10]. The subtypes of macrophages within a tumor is heterogeneous [11]; in general however, tumor development is associated with the presence of macrophages with M2-like characteristics, particularly in patients with a poor prognosis $[8,12-14]$. M2like macrophages function in the resolution of inflammation and in protection and repair of damaged tissue [15-18]. One of the basic functions of M2-like macrophages that is associated with tissue protection and repair is immunosuppression [11], and tumors have generally been found to contain macrophages with immunosuppressive characteristics [5, 19-22].

Another important myeloid cell population that is associated with tumors are myeloid-derived suppressor cells, and there is almost universal agreement that accumulation of myeloid cells with MDSC-like phenotypes in the blood or tumor correlates with disease progression, poor prognosis, poor response to therapy, and decreased overall survival [23-29]. MDSCs are associated with tumor progression in mouse models of mesothelioma [30-32], and MDSCs are believed to be associated with mesotheliomas in human patients [33, 34].

$\mathrm{C}-\mathrm{C}$ motif chemokine ligand 2 (CCL2), also known as monocyte chemotactic protein-1 (MCP-1), is expressed in most human cancers [35-37], and plays a key role in the recruitment of macrophages and MDSCs [35, 36, 38-40]. In general agreement with the findings that tumors accumulate macrophages and MDSCs that have pro-tumorigenic properties and express CCL2 and that CCL2 expression in tumor tissue is associated with advanced tumor stage and worse prognosis, there are several studies that report elevated levels of CCL2 in the serum of cancer patients and/or an association between elevated serum CCL2 and poor prognosis [41-51]. Other studies, however, found either no association between the serum CCL2 levels of cancer patients and clinical variables or that lower serum CCL2 levels were associated with poor prognosis or that higher serum CCL2 levels were associated with favorable prognosis [52-60].

Whether the disparate findings of the studies cited above are due to differences in tumor stage, CCL2 being associated with a tumorigenic response in some cases and to a tumoricidal response in others, differing immune suppression mechanisms in different tumor types or the patient cohorts studied, or to some other factor is not known. It is clear, however, that the role of CCL2 in tumorigenesis is likely to be affected by tumor-specific factors. The current study was undertaken to investigate serum CCL2 levels in mesothelioma patients. We found that serum CCL2 levels were increased in mesothelioma patients and that this increase was dependent on advancing mesothelioma stage.

\section{Methods \\ Subjects}

Healthy, unexposed volunteers (41 volunteers; 10 females and 31 males; age $56 \pm 20.0$ years; Range 23-91 years): Serum samples were collected from teaching and research staff at the Nagoya City University Graduate School of Medical Sciences and residents/patients at Nogoyashi Koseiin Medical Welfare Center Hospital (Koseiin Hospital). These subjects had no history of exposure to asbestos and were free from lung and pleural lesions on periodical (once or twice a year) institutional health examinations.

Healthy subjects possibly exposed to asbestos (356 subjects; 33 females and 323 males; age $68.7 \pm 8.3$ years; Range 35-96 years): Serum samples were collected from patients who visited or were hospitalized in the Japan Labour Health and Welfare Organization Asahi Rosai Hospital and the Saiseikai Chuwa Hospital. All of the enrolled subjects possibly exposed to asbestos had certified documents issued by the Japanese Ministry of Health, Labour and Welfare for the compensation of medical care. These subjects had no detectable asbestosassociated disease. Since the hospital records of patients not suffering from mesothelioma were not available to us, it is not known whether any of the subjects in this group had a health condition or treatment that would increase their serum CCL2 levels, for example see patient 356 (Additional file 1: Table S1). However, while there was a tendency for this group to have higher serum CCL2 levels compared to the healthy, unexposed volunteers, the difference between these groups was not statistically significant.

Mesothelioma patients (50 patients; 5 females and 45 males; age $72.5 \pm 8.6$ years; Range $57-99$ years): Serum samples were collected from patients who were hospitalized in the Okayama Rosai Hospital, Asahi Rosai Hospital, Saiseikai Chuwa Hospital, Daido Hospital, and Nagoya City University Hospital. The diagnosis of MPM was made by biopsy examination combined with chest computed tomography examinations. Histological types of MPM were sarcomatoid, epithelioid, and biphasic.

All participants were provided written informed consent before inclusion in the study. Serum samples were then obtained, coded, and stored in aliquots at $-80^{\circ} \mathrm{C}$ until use. 


\section{Assay method}

Enzyme-linked immune-absorbent assay (ELISA) kits (CCL2: DCP00, R\&D systems, Minneapolis, USA) were used for measuring CCL2, following the manufacturer's instructions. The minimum detectable level of human CCL2 ranged between 0.57 and $10.0 \mathrm{pg} / \mathrm{ml}$ for these ELISA kits. All samples had measured CCL2 levels above the minimum detectable levels.

\section{Statistics}

In Table 1, patient age and serum CCL2 levels are presented as mean \pm SD. In Tables 2, 3, 4 and 5, Analysis of Variance (ANOVA) was used to calculate the estimated marginal means and standard errors. Fisher's exact test was used to test the significance of the differences of the nominal data (the data pertaining to gender). The Kruskal-Wallis (one-way ANOVA) test was used to test the significance of the differences in patient age. Analysis of covariance (ANCOVA) was used to compare the estimated marginal means of serum CCL2 levels adjusted for the covariates of age and gender. The homogeneity of the variance of the serum CCL2 levels was tested using Welch's test. The significance of the differences between the means was tested using the Bonferroni test when the variance was homogenous and Tamhane's T2 test when the variance was not homogenous. $p$-values were determined using pairwise comparison tests (pairwise comparisons are shown in Additional file 3: Tables $\mathrm{S} 3$ - S8). $p$-values $<0.05$ were considered statistically significant. All statistical analyses were carried out with statistical software package SPSS 24.0 (SPSS, Chicago, IL, USA).

\section{Results}

A summary of the gender, age, and serum CCL2 levels of the study subjects is shown in Table 1. Individual CCL2 levels are shown in Additional file 1: Table S1. The pairwise comparisons of the groups is shown in
Additional file 3: Tables S3 and S4. The mean CCL2 level in the serum of the mesothelioma patients is significantly elevated compared to the Possibly Exposed (no apparent disease) group, and this increase is dependent on the stage of the disease.

It is known that serum CCL2 levels increase with age [61-63], and as can be seen in Table 1 the mean CCL2 level in the serum of the Possibly Exposed (no apparent disease) group, age $68.7 \pm 8.3$ yrs., is higher than that of the Unexposed (no apparent disease) group, age $56.0 \pm$ 20.0 yrs.: the age ranges of the study participants are shown in Additional file 2: Table S2. Analysis of the age of the patients using the Kruskal-Wallis (one-way ANOVA) test shows an age difference between the patients in the different groups $(p<0.05)$. Fisher's exact test also shows a gender difference between groups $(p<0.05)$ : see Methods for the gender of the study participants. Therefore, the data was re-analyzed based on covariates of age (67.97) and gender (1.11). In Tables 2, 3, 4 and 5, Analysis of Variance (ANOVA) was used to calculate the estimated marginal means and standard error. Subsequently, Analysis of covariance (ANCOVA) was used to compare the estimated marginal means adjusted for covariates of age and gender.

Tables 2 and 3 show the unadjusted serum CCL2 means and 95\% confidence intervals and the estimated CCL2 means and 95\% confidence intervals when the data is adjusted based on the covariates of age and gender. In Table 2, the data was adjusted using the Unexposed (no apparent disease), Possibly Exposed (no apparent disease), and Mesothelioma (all patients) groups. The pairwise comparisons of these groups is shown in Additional file 3: Table S5. In Table 3, the data was adjusted using the Unexposed (no apparent disease), Possibly Exposed (no apparent disease), and Mesothelioma stages 1-4 groups. The pairwise comparisons of these groups is shown in Additional file 3: Table S6. After adjusting the data, the estimated mean CCL2 level

Table 1 Gender, age, and serum CCL2 levels of the study subjects. (Individual patient data is shown in Additional file 1: Table S1)

\begin{tabular}{|c|c|c|c|c|c|}
\hline & \multirow[t]{2}{*}{ Number of Patients } & \multicolumn{2}{|l|}{ Gender } & \multirow[t]{2}{*}{ Age } & \multirow{2}{*}{$\begin{array}{l}\text { Serum CCL2 } \\
(\mathrm{pg} / \mathrm{ml})\end{array}$} \\
\hline & & Women & Men & & \\
\hline Unexposed (no apparent disease) & 41 & 10 & 31 & $56.0 \pm 20.0$ & $275.2 \pm 98.2$ \\
\hline Possibly Exposed (no apparent disease) & 356 & 33 & 323 & $68.7 \pm 8.3$ & $307.5 \pm 117.7$ \\
\hline Mesothelioma (all patients) & 50 & 5 & 45 & $72.5 \pm 8.6$ & $421.3 \pm 295.1^{\mathrm{a}, \mathrm{b}}$ \\
\hline Mesothelioma (stage 1 patients) & 12 & 0 & 12 & $72.8 \pm 9.1$ & $289.9 \pm 115.4$ \\
\hline Mesothelioma (stage 2 patients) & 5 & 0 & 5 & $75.6 \pm 7.1$ & $281.0 \pm 111.2$ \\
\hline Mesothelioma (stage 3 patients) & 14 & 1 & 13 & $74.3 \pm 10.7$ & $486.0 \pm 333.4^{c, d}$ \\
\hline Mesothelioma (stage 4 patients) & 19 & 4 & 15 & $70.2 \pm 6.8$ & $493.5 \pm 346.7^{c, d}$ \\
\hline
\end{tabular}

${ }^{\mathrm{a}}$ Different from the Unexposed (no apparent disease) group at $p<0.01$

${ }^{\mathrm{b}}$ Different from the Possibly Exposed (no apparent disease) group at $p<0.05$

'Different from the Unexposed (no apparent disease) and the Possibly Exposed (no apparent disease) groups at $p<0.001$

${ }^{\mathrm{d} D i f f e r e n t}$ from the Mesothelioma (stage 1 patients) group at $p<0.01$ 
Table 2 Serum CCL2 levels of the study subjects after adjusting the data for the covariates of gender and age

\begin{tabular}{|c|c|c|c|c|c|c|c|c|}
\hline & \multicolumn{4}{|c|}{ Unadjusted Data (ANOVA) } & \multicolumn{4}{|c|}{ Adjusted Data (ANCOVA) } \\
\hline & \multirow{2}{*}{$\begin{array}{l}\text { Serum CCL2 } \\
(\mathrm{pg} / \mathrm{ml})\end{array}$} & \multirow{2}{*}{$\begin{array}{l}\text { Std } \\
\text { Error }\end{array}$} & \multicolumn{2}{|l|}{$95 \% \mathrm{Cl}$} & \multirow{2}{*}{$\begin{array}{l}\text { Estimated Serum } \\
\text { CCL2 (pg/ml) }\end{array}$} & \multirow{2}{*}{$\begin{array}{l}\text { Std } \\
\text { Error }\end{array}$} & \multicolumn{2}{|l|}{$95 \% \mathrm{Cl}$} \\
\hline & & & Lower Limit & Upper Limit & & & Lower Limit & Upper Limit \\
\hline Unexposed (no apparent disease) & 275.2 & 22.9 & 230.2 & 320.3 & 303.5 & 24.2 & 256.0 & 351.1 \\
\hline Possibly Exposed (no apparent disease) & 307.5 & 7.8 & 292.2 & 322.8 & 305.6 & 7.7 & 290.4 & 320.8 \\
\hline Mesothelioma (all patients) & $421.3^{\mathrm{a}, \mathrm{c}}$ & 20.8 & 380.5 & 462.1 & $411.8^{\mathrm{b}, \mathrm{c}}$ & 20.8 & 370.9 & 452.6 \\
\hline
\end{tabular}

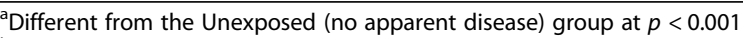

${ }^{\mathrm{b}}$ Different from the Unexposed (no apparent disease) group at $p<0.01$

'Different from the Possibly Exposed (no apparent disease) group at $p<0.001$

in the serum of the mesothelioma patients is significantly elevated compared to the Possibly Exposed (no apparent disease) group, and this increase is dependent on the stage of the disease.

Two patients in the Mesothelioma group, patients 31 and 50 (Additional file 1: Table S1), had extraordinarily high levels of serum CCL2. Removal of these two patients reduces the serum CCL2 levels in the mesothelioma all patients, stage 3 patients, and stage 4 patients groups to $368.5 \pm 138.1,402.7 \pm 123.2$, and $420.5 \pm 141.9$, respectively. Tables 4 and 5 show the results when these two patients are removed from data analysis. Table 4 shows the unadjusted serum CCL2 means and 95\% confidence intervals and the estimated CCL2 means and 95\% confidence intervals when the data is adjusted based on the covariates of age and gender using the Unexposed (no apparent disease), Possibly Exposed (no apparent disease), and Mesothelioma (all patients) groups. The pairwise comparisons of these groups is shown in Additional file 3: Table S7. Table 5 shows the unadjusted serum CCL2 means and 95\% confidence intervals and the estimated CCL2 means and 95\% confidence intervals when the data is adjusted based on the covariates of age and gender using the Unexposed (no apparent disease), Possibly Exposed (no apparent disease), and Mesothelioma stages 1-4 groups. The pairwise comparisons of these groups is shown in Additional file 3: Table S8.
After removal of patients 31 and 50 from the data analysis, CCL2 levels in the mesothelioma patients are still significantly higher than the CCL2 levels in the Unexposed (no apparent disease) and the Possibly Exposed (no apparent disease) groups, and this increase is dependent on the stage of the disease.

\section{Discussion}

In this study we measured the levels of CCL2 in the serum of 41 healthy volunteers who have not been exposed to asbestos, 356 healthy subjects who have possibly been exposed to asbestos, and 50 mesothelioma patients. The mean CCL2 level in the serum of the mesothelioma patients was significantly elevated compared to both the healthy volunteers who have not been exposed to asbestos and the healthy subjects who have possibly been exposed to asbestos (see Table 1). However, it is known that serum CCL2 levels increase with normal aging [61-63], and analysis of the age of the patients using the Kruskal-Wallis (one-way ANOVA) test showed an age difference between the patients in the Possibly Exposed (no apparent disease) and the mesothelioma groups. Fisher's exact test also showed a gender difference between these groups. Therefore, the data was re-analyzed based on covariates of age (67.97) and gender (1.11). Re-analysis of the data after adjusting for age and gender did not change the conclusions of the study:

Table 3 Serum CCL2 levels of the study subjects after adjusting the data for the covariates of gender and age

\begin{tabular}{|c|c|c|c|c|c|c|c|c|}
\hline & \multicolumn{4}{|c|}{ Unadjusted Data (ANOVA) } & \multicolumn{4}{|l|}{ Adjusted Data (ANCOVA) } \\
\hline & \multirow{2}{*}{$\begin{array}{l}\text { Serum CCL2 } \\
(\mathrm{pg} / \mathrm{ml})\end{array}$} & \multirow{2}{*}{$\begin{array}{l}\text { Std } \\
\text { Error }\end{array}$} & \multicolumn{2}{|l|}{$95 \% \mathrm{Cl}$} & \multirow{2}{*}{$\begin{array}{l}\text { Estimated Serum CCL2 } \\
(\mathrm{pg} / \mathrm{ml})\end{array}$} & \multirow{2}{*}{$\begin{array}{l}\text { Std } \\
\text { Error }\end{array}$} & \multicolumn{2}{|l|}{$95 \% \mathrm{Cl}$} \\
\hline & & & Lower Limit & Upper Limit & & & Lower Limit & Upper Limit \\
\hline Unexposed (no apparent disease) & 275.2 & 22.9 & 230.2 & 320.3 & 305.5 & 24.2 & 256.0 & 351.1 \\
\hline Possibly Exposed (no apparent disease) & 307.5 & 7.8 & 292.2 & 322.8 & 305.4 & 7.7 & 290.4 & 320.8 \\
\hline Mesothelioma (stage 1 patients) & 289.9 & 41.5 & 208.4 & 371.4 & 275.7 & 41.1 & 195.0 & 356.5 \\
\hline Mesothelioma (stage 2 patients) & 281.0 & 64.4 & 154.7 & 407.3 & 261.0 & 63.6 & 136.0 & 386.0 \\
\hline Mesothelioma (stage 3 patients) & $486.0^{a, c, d}$ & 38.4 & 410.5 & 561.5 & $471.4^{\mathrm{b}, \mathrm{c}, \mathrm{d}}$ & 38.1 & 396.4 & 546.3 \\
\hline Mesothelioma (stage 4 patients) & $493.5^{\mathrm{a}, \mathrm{c}, \mathrm{d}}$ & 33.0 & 428.7 & 558.3 & $492.5^{\mathrm{a}, \mathrm{c}, \mathrm{d}, \mathrm{e}}$ & 32.7 & 428.3 & 556.7 \\
\hline
\end{tabular}

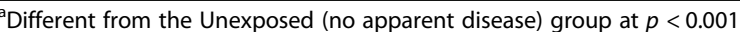

${ }^{\mathrm{b}}$ Different from the Unexposed (no apparent disease) group at $p<0.01$

'Different from the Possibly Exposed (no apparent disease) group at $p<0.001$

${ }^{\mathrm{d} D i f f e r e n t}$ from the Mesothelioma stage 1 patients group at $p<0.01$

e Different from the Mesothelioma stage 2 patients group at $p<0.05$ 
Table 4 Serum CCL2 levels of the study subjects after removing patients 31 and 50 and adjusting the data for the covariates of gender and age

\begin{tabular}{|c|c|c|c|c|c|c|c|c|}
\hline & \multicolumn{4}{|c|}{ Unadjusted Data (ANOVA) } & \multicolumn{4}{|l|}{ Adjusted Data (ANCOVA) } \\
\hline & \multirow{2}{*}{$\begin{array}{l}\text { Serum CCL2 } \\
(\mathrm{pg} / \mathrm{ml})\end{array}$} & \multirow{2}{*}{$\begin{array}{l}\text { Std } \\
\text { Error }\end{array}$} & \multicolumn{2}{|l|}{$95 \% \mathrm{Cl}$} & \multirow{2}{*}{$\begin{array}{l}\text { Estimated Serum CCL2 } \\
(\mathrm{pg} / \mathrm{ml})\end{array}$} & \multirow{2}{*}{$\begin{array}{l}\text { Std } \\
\text { Error }\end{array}$} & \multicolumn{2}{|l|}{$95 \% \mathrm{Cl}$} \\
\hline & & & Lower Limit & Upper Limit & & & Lower Limit & Upper Limit \\
\hline Unexposed (no apparent disease) & 275.2 & 18.5 & 238.9 & 311.6 & 308.6 & 19.3 & 270.7 & 346.4 \\
\hline Possibly Exposed (no apparent disease) & 307.5 & 6.3 & 295.2 & 319.9 & 305.4 & 6.1 & 293.3 & 317.4 \\
\hline Mesothelioma (all patients) & $368.5^{\mathrm{a}}$ & 17.1 & 334.9 & 402.1 & $356.0^{\mathrm{b}}$ & 16.9 & 322.8 & 389.2 \\
\hline
\end{tabular}

Different from the Unexposed (no apparent disease) and the Possibly Exposed (no apparent disease) groups at $p<0.01$

${ }^{b}$ Different from the Possibly Exposed (no apparent disease) groups at $p<0.05$

serum CCL2 was elevated in mesothelioma patients (see Table 2). Mesothelioma patients 31 and 50 (see Additional file 1: Table S1) had exceptionally high levels of CCL2. After removal of these two patients' data from analysis, serum CCL2 was still elevated in mesothelioma patients (see Table 4). Therefore, our data indicate that serum CCL2 levels were increased in mesothelioma patients and this increase was not dependent on the age of the patients in the Mesothelioma group or on the presence of the two patients in the Mesothelioma group with exceptionally high levels of serum CCL2. Elevated CCL2 in the serum of mesothelioma patients is in agreement with the high levels of CCL2 present in the pleural effusions of mesothelioma patients reported by Gueugnon et al. [64].

The increase in the serum levels of CCL2 in the mesothelioma patients was dependent on the stage of the disease (see Table 1). Reanalysis of the data adjusting for age and gender also indicated elevated levels of serum CCL2 depended on mesothelioma stage (see Tables 2 and 3). The dependence on mesothelioma stage was still apparent after removal of the two mesothelioma patients with exceptionally high levels of serum CCL2 from data analysis (see Tables 4 and 5). Therefore, as with the increase in the levels of CCL2 in the serum of mesothelioma patients, the dependence of this increase on disease stage was not due to the age of the patients in the
Mesothelioma group or on the presence of the two patients in the Mesothelioma group with exceptionally high levels of serum CCL2.

The mean CCL2 level in the serum of the healthy subjects who have possibly been exposed to asbestos was elevated compared to the healthy volunteers who have not been exposed to asbestos. However, as noted above, it is known that serum CCL2 levels increase during normal ageing [61-63]. Thus, the levels of CCL2 in the serum in these two groups followed the expected pattern, lower in the healthy unexposed group consisting of primarily younger patients and higher in the healthy possibly exposed group consisting of primarily older patients.

Several studies have reported that increased expression of CCL2 in tumor tissue is associated with advanced tumor stage and worse prognosis: These studies include patients with breast cancer [65-68], prostate cancer [69, 70], gastric cancer [71], colorectal cancer [72, 73], esophageal squamous cell carcinoma [74], head and neck squamous cell carcinoma [75], and glial tumors [47]. In agreement with these findings, a number of studies report elevated levels of CCL2 in the serum of cancer patients and/or an association between elevated serum CCL2 and poor prognosis: Moogooei et al. [47] and Pan et al. [48] report elevated levels of serum CCL2 in patients with glial tumors and lung cancer. Lu et al. [45] and Sharma et al. [49] report an association between

Table 5 Serum CCL2 levels of the study subjects after removing patients 31 and 50 and adjusting the data for the covariates of gender and age

\begin{tabular}{|c|c|c|c|c|c|c|c|c|}
\hline & \multicolumn{4}{|c|}{ Unadjusted Data (ANOVA) } & \multicolumn{4}{|l|}{ Adjusted Data (ANCOVA) } \\
\hline & \multirow{2}{*}{$\begin{array}{l}\text { Serum CCL2 } \\
(\mathrm{pg} / \mathrm{ml})\end{array}$} & \multirow{2}{*}{$\begin{array}{l}\text { Std } \\
\text { Error }\end{array}$} & \multicolumn{2}{|l|}{$95 \% \mathrm{Cl}$} & \multirow{2}{*}{$\begin{array}{l}\text { Estimated Serum CCL2 } \\
(\mathrm{pg} / \mathrm{ml})\end{array}$} & \multirow{2}{*}{$\begin{array}{l}\text { Std } \\
\text { Error }\end{array}$} & \multicolumn{2}{|l|}{$95 \% \mathrm{Cl}$} \\
\hline & & & Lower Limit & Upper Limit & & & Lower Limit & Upper Limi \\
\hline Unexposed (no apparent disease) & 275.2 & 18.3 & 239.3 & 311.2 & 305.5 & 24.2 & 256.0 & 351.1 \\
\hline Possibly Exposed (no apparent disease) & 307.5 & 6.2 & 295.3 & 319.7 & 305.4 & 7.7 & 290.4 & 320.8 \\
\hline Mesothelioma (stage 1 patients) & 289.9 & 33.8 & 223.5 & 356.4 & 275.7 & 41.1 & 195.0 & 356.5 \\
\hline Mesothelioma (stage 2 patients) & 281.0 & 52.4 & 178.1 & 383.9 & 261.0 & 63.6 & 136.0 & 386.0 \\
\hline Mesothelioma (stage 3 patients) & $402.7^{\mathrm{b}}$ & 32.5 & 338.9 & 466.5 & 471.4 & 38.1 & 396.4 & 546.3 \\
\hline Mesothelioma (stage 4 patients) & $420.5^{a, c, d}$ & 27.6 & 366.3 & 474.8 & $492.5^{b, c, d}$ & 32.7 & 428.3 & 556.7 \\
\hline
\end{tabular}

${ }^{\mathrm{a} D i f f e r e n t ~ f r o m ~ t h e ~ U n e x p o s e d ~(n o ~ a p p a r e n t ~ d i s e a s e) ~ g r o u p ~ a t ~} p<0.001$

${ }^{\mathrm{b}}$ Different from the Unexposed (no apparent disease) group at $p<0.05$

'Different from the Possibly Exposed (no apparent disease) group at $p<0.01$

${ }^{\mathrm{d} D i f f e r e n t}$ from the Mesothelioma stage 1 patients group at $p<0.05$ 
elevated serum CCL2 levels and poor prognosis in patients with prostate cancer, and Lu et al. [44] report an association between elevated serum CCL2 levels and poor prognosis in patients with nasopharyngeal cancer. Cai et al. [41], Wang et al. [50], Wu et al. [51], Lubowicka et al. [46], and Hefler et al. [42] report elevated levels of serum CCL2 in patients with lung, liver, gastric, breast, and ovarian cancer and that increased serum CCL2 was associated with poor prognosis. Lebrecht et al. [43] did not find a difference in serum CCL2 levels between breast cancer patients and normal donors, but they did find an association between serum CCL2 and poor prognosis.

However, there are also reports that increased expression of CCL2 in tumor tissue is associated with better prognosis: These studies include patients with gastric cancer [59], colorectal cancer [76], liver cancer [77], and nonsmall cell lung cancer [78]. There are also a number of studies, that report either that serum CCL2 levels in cancer patients are not related to clinical variables or that higher serum CCL2 levels are associated with a better prognosis and/or that lower serum CCL2 levels are associated with worse prognosis. Tas et al. [58], Tsaur et al. [60], and Monti et al. [56] found elevated serum CCL2 levels in patients with gastric, prostate, and pancreas cancer. However, Tas et al. report that while gastric cancer patients who responded to chemotherapy had lower serum CCL2 than non-responders, there was no association between serum CCL2 and any measured clinical variables; Tsuar et al. report that elevated serum CCL2 was negatively correlated with PSA value in prostate cancer patients; and Monti et al. report that elevated serum CCL2 was associated with increased survival in pancreas cancer patients. Farren et al. [54] also report that elevated serum CCL2 levels correlated with increased survival in pancreas cancer patients. Sullivan et al. [57] report that there was no difference in serum CCL2 levels between pancreas cancer patients and normal donors and that serum CCL2 did not correlate with any measured clinico-pathological parameters. Koper et al. [55], Ding et al. [53], and Tonouchi et al. [59] report that serum CCL2 levels were decreased in patients with astrocytic brain tumors, oral squamous cell carcinoma, and gastric cancer, and Tonouchi et al. report CCL2 levels tended to decrease in accordance with disease progression and that decreased serum CCL2 levels were associated with poor survival. Dehqanzada et al. [52] report that elevated serum CCL2 levels correlated with favorable prognostic variables in patients with breast cancer.

Thus, the association between serum CCL2 levels and different cancers appears to be variable. Since mesotheliomas are heavily infiltrated by macrophages [7-10] and likely to be infiltrated by MDSCs [33, 34], our finding that CCL2 is elevated in the serum of patients with advanced mesothelioma is consistent with a disease in which the CCL2/CCR2 axis and myeloid-derived cells play an important part. Consequently, therapies that prove effective against other cancers in which the CCL2/ CCR2 axis and myeloid-derived cells are associated with disease progression may also prove effective with mesothelioma patients. There is considerable interest in developing therapies that target CCL2/CCR2 and tumorresident myeloid cells [5, 22, 79-85]. Numerous clinical trials employing these therapies as part of the treatment regimen have been carried out or are currently being pursued [86-94]. The success or failure of these trials will have important implications for the treatment of mesothelioma. Another aspect of increased CCL2 in the serum of mesothelioma patients is that it may be possible to use serum CCL2 to monitor a patient's response to treatment [95].

\section{Conclusions}

CCL2 levels are elevated in mesothelioma patients and the increase is dependent on the stage of the disease. This is consistent with the premise that the CCL2/CCR2 axis and myeloid-derived cells play an important role in mesothelioma and disease progression. Other types of cancer also cause stage-dependent increases in serum CCL2. Therapies are being developed that target CCL2/ CCR2 and tumor resident myeloid cells, and clinical trials are being pursued that use these therapies as part of the treatment regimen. The results of trials with patients with a similar pattern of CCL2 as mesothelioma patients will have important implications for the treatment of mesothelioma.

\section{Supplementary information}

Supplementary information accompanies this paper at https://doi.org/10. 1186/s12885-019-6419-1.

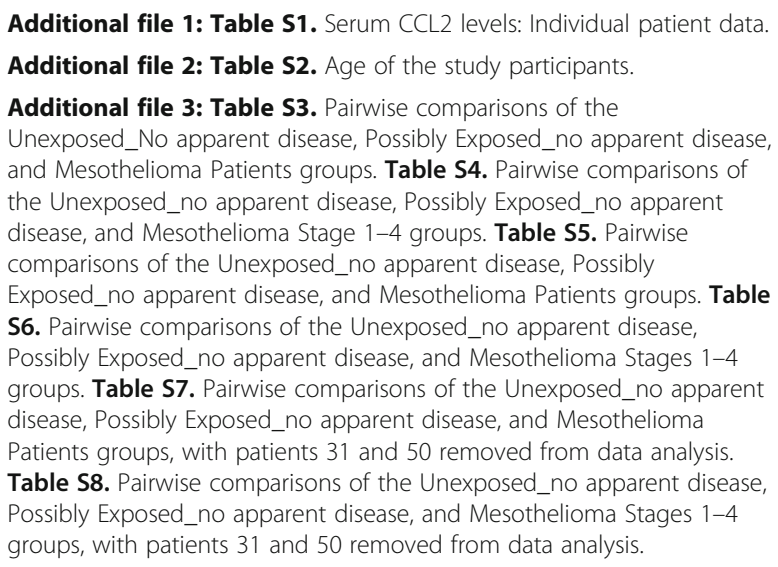

Abbreviations

CCL2: C-C motif chemokine ligand 2; MCP-1: Monocyte chemotactic protein1; MDSC: Myeloid-derived suppressor cell; MPM: Malignant pleural mesothelioma 


\section{Acknowledgments}

None.

\section{Authors' contributions}

TK: Conception of the study, acquisition of patient samples, data analysis. NF: Acquisition of patient samples. TE: Data analysis and interpretation. TOmori Conception of the study. TOguri: Acquisition of patient samples. AN: Acquisition of patient samples. TY: Acquisition of patient samples. MK: Acquisition of patient samples. IU: Acquisition of patient samples. MN: Acquisition of patient samples. KY: Acquisition of patient samples. TT: Acquisition of patient samples. MT: Acquisition of patient samples. YY: Acquisition of patient samples. KT: Data analysis and interpretation. YM: Data analysis and interpretation. JX: Draft the manuscript. ST: Data interpretation, draft the manuscript. MA: Perform ELISAs, draft the manuscript. WTA: Perform ELISAs, draft the manuscript. DBA: Perform ELISAs, draft the manuscript. HT Conception of the study, draft the manuscript. All authors have read and approved the manuscript.

\section{Funding}

This study was supported by the Ministry of Health, Labour, and Welfare of Japan (Grant Numbers: 14030101-01, 13801370, 16768893) and by the Princess Takamatsu Cancer Research Fund (Grant Number: 'H24'). The funding bodies had no role in the design of the study, data collection, analysis, or interpretation of data, the writing of the manuscript, or the decision to submit the manuscript for publication.

\section{Availability of data and materials}

All data is available in Addition file S1.

\section{Ethics approval and consent to participate}

All participants were provided written informed consent before inclusion in the study. This study was conducted under the approval of the ethics committees of the Nogoyashi Koseiin Medical Welfare Center Hospital, Okayama Rosai Hospital, Asahi Rosai Hospital, Saiseikai Chuwa Hospital, Daido Hospital, and Nagoya City University for the use of materials and analysis.

\section{Consent for publication}

Not applicable.

\section{Competing interests}

The authors declare that they have no competing interests.

\section{Author details}

'Japan Organization of Occupational Health and Safety, Research Center for Asbestos-related Diseases, Okayama Rosai Hospital, Okayama, Japan. 2Department of Occupational and Environmental Health, Nagoya City University Graduate School of Medical Sciences, Nagoya, Japan. ${ }^{3}$ Department of Healthcare Policy and Management, Nagoya City University Graduate School of Medical Sciences, Nagoya, Japan. ${ }^{4}$ Department of Respiratory Medicine, Allergy and Clinical Immunology, Nagoya City University Graduate School of Medical Sciences, Nagoya, Japan. ${ }^{5}$ Japan Organization of Occupational Health and Safety, Department of Respiratory Medicine, Asahi Rosai Hospital, Owariasahi, Japan. ${ }^{6}$ Department of Respiratory Medicine, Daido Hospital, Nagoya, Japan. D. Chuwa Hospital, Sakurai, Nara, Japan. ${ }^{8}$ Department of Internal Medicine, National Hospital Organization Nara Medical Center, Nara, Japan. ${ }^{9}$ Department of Medicine and Physical Medicine and Rehabilitation, Nagoya City Koseiin Medical Welfare Center, Nagoya, Japan. ${ }^{10}$ Department of Gastroenterological Surgery, Nagoya City University Graduate School of Medical Sciences, Nagoya, Japan. ${ }^{11}$ Department of Immunology, College of Basic Medical Sciences, Anhui Medical University, Hefei, China.

${ }^{12}$ Nanotoxicology Project Lab, Nagoya City University, 3-1 Tanabedohri, Mizuho-ku, Nagoya 467-8603, Japan. ${ }^{13}$ Department of Experimental Pathology and Tumor Biology, Nagoya City University Graduate School of Medical Sciences, Nagoya, Japan. ${ }^{14}$ Department of Forensic Medicine and Toxicology, Faculty of Veterinary Medicine, Beni-Suef University, Beni-Suef, Egypt.
Received: 17 August 2019 Accepted: 1 December 2019

Published online: 10 December 2019

\section{References}

1. IARC monographs on the evaluation of carcinogenic risk of chemicals to man. Some inorganic and organometallic compounds. Volume 2. A Review of Human Carcinogens. Lyon, France, 1973. 1973.

2. IARC Monographs on the Evaluation of Carcinogenic Risks to Humans. Arsenic, Metals, Fibres, and Dusts. Volume 100C. A Review of Human Carcinogens. Lyon, France, 2012. 2012.

3. Vainio H, Oksa P, Tuomi T, Vehmas T, Wolff H. Helsinki criteria update 2014: asbestos continues to be a challenge for disease prevention and attribution. Epidemiol Prev. 2016:40(1 Suppl 1):15-9.

4. Furuya S, Chimed-Ochir O, Takahashi K, David A, Takala J. Global asbestos disaster. Int J Environ Res Public Health. 2018;15(5):E1000.

5. Mantovani A, Marchesi F, Malesci A, Laghi L, Allavena P. Tumour-associated macrophages as treatment targets in oncology. Nat Rev Clin Oncol. 2017; 14(7):399-416.

6. Qian BZ, Pollard JW. Macrophage diversity enhances tumor progression and metastasis. Cell. 2010;141(1):39-51.

7. Burt BM, Rodig SJ, Tilleman TR, Elbardissi AW, Bueno R, Sugarbaker DJ. Circulating and tumor-infiltrating myeloid cells predict survival in human pleural mesothelioma. Cancer. 2011;117(22):5234-44.

8. Cornelissen R, Lievense LA, Maat AP, Hendriks RW, Hoogsteden HC, Bogers AJ, Hegmans JP, Aerts JG. Ratio of intratumoral macrophage phenotypes is a prognostic factor in epithelioid malignant pleural mesothelioma. PLoS One. 2014;9(9):e106742.

9. Hegmans JP, Hemmes A, Hammad H, Boon L, Hoogsteden HC, Lambrecht BN. Mesothelioma environment comprises cytokines and T-regulatory cells that suppress immune responses. Eur Respir J. 2006:27(6):1086-95.

10. Lievense LA, Bezemer K, Aerts JG, Hegmans JP. Tumor-associated macrophages in thoracic malignancies. Lung Cancer. 2013;80(3):256-62.

11. Murray PJ. Nonresolving macrophage-mediated inflammation in malignancy. FEBS J. 2018;285(4):641-53.

12. Chene AL, d'Almeida S, Blondy T, Tabiasco J, Deshayes S, Fonteneau JF, Cellerin L, Delneste Y, Gregoire M, Blanquart C. Pleural effusions from patients with mesothelioma induce recruitment of monocytes and their differentiation into M2 macrophages. J Thorac Oncol. 2016;11(10):1765-73.

13. Mills CD, Lenz LL, Harris RA. A breakthrough: macrophage-directed Cancer immunotherapy. Cancer Res. 2016;76(3):513-6.

14. Takeya M, Komohara Y. Role of tumor-associated macrophages in human malignancies: friend or foe? Pathol Int. 2016:66(9):491-505.

15. Italiani $P$, Boraschi D. New insights into tissue macrophages: from their origin to the development of memory. Immune Netw. 2015;15(4):167-76.

16. Mantovani A. From phagocyte diversity and activation to probiotics: back to Metchnikoff. Eur J Immunol. 2008;38(12):3269-73.

17. Martinez FO, Gordon S. The M1 and M2 paradigm of macrophage activation: time for reassessment. F1000Prime Rep. 2014:6:13.

18. Sica A, Mantovani A. Macrophage plasticity and polarization: in vivo veritas. J Clin Invest. 2012;122(3):787-95.

19. Allavena P, Sica A, Solinas G, Porta C, Mantovani A. The inflammatory microenvironment in tumor progression: the role of tumor-associated macrophages. Crit Rev Oncol Hematol. 2008:66(1):1-9.

20. Chanmee T, Ontong P, Konno K, Itano N. Tumor-associated macrophages as major players in the tumor microenvironment. Cancers (Basel). 2014;6(3): 1670-90.

21. Hao NB, Lu MH, Fan YH, Cao YL, Zhang ZR, Yang SM. Macrophages in tumor microenvironments and the progression of tumors. Clin Dev Immunol. 2012:2012:948098.

22. Noy R, Pollard JW. Tumor-associated macrophages: from mechanisms to therapy. Immunity. 2014;41(1):49-61.

23. Ai L, Mu S, Wang Y, Wang H, Cai L, Li W, Hu Y. Prognostic role of myeloidderived suppressor cells in cancers: a systematic review and meta-analysis. BMC Cancer. 2018:18(1):1220.

24. Diaz-Montero CM, Salem ML, Nishimura MI, Garrett-Mayer E, Cole DJ, Montero AJ. Increased circulating myeloid-derived suppressor cells correlate with clinical cancer stage, metastatic tumor burden, and doxorubicincyclophosphamide chemotherapy. Cancer Immunol Immunother. 2009; 58(1):49-59.

25. Dumitru CA, Moses K, Trellakis S, Lang S, Brandau S. Neutrophils and granulocytic myeloid-derived suppressor cells: immunophenotyping, cell 
biology and clinical relevance in human oncology. Cancer Immunol Immunother. 2012;61(8):1155-67.

26. Ohki S, Shibata M, Gonda K, Machida T, Shimura T, Nakamura I, Ohtake T, Koyama Y, Suzuki S, Ohto H, et al. Circulating myeloid-derived suppressor cells are increased and correlate to immune suppression, inflammation and hypoproteinemia in patients with cancer. Oncol Rep. 2012;28(2):453-8.

27. Okla K, Wertel I, Wawruszak A, Bobinski M, Kotarski J. Blood-based analyses of cancer: circulating myeloid-derived suppressor cells - is a new era coming? Crit Rev Clin Lab Sci. 2018:55(6):376-407.

28. Veglia F, Perego M, Gabrilovich D. Myeloid-derived suppressor cells coming of age. Nat Immunol. 2018;19(2):108-19.

29. Zhang S, Ma X, Zhu C, Liu L, Wang G, Yuan X. The role of myeloid-derived suppressor cells in patients with solid tumors: a meta-analysis. PLoS One. 2016;11(10):e0164514.

30. Tan Z, Zhou J, Cheung AK, Yu Z, Cheung KW, Liang J, Wang H, Lee BK, Man $K$, Liu $L$, et al. Vaccine-elicited CD8+ T cells cure mesothelioma by overcoming tumor-induced immunosuppressive environment. Cancer Res. 2014;74(21):6010-21.

31. Veltman JD, Lambers ME, van Nimwegen M, Hendriks RW, Hoogsteden HC, Aerts JG, Hegmans JP. COX-2 inhibition improves immunotherapy and is associated with decreased numbers of myeloid-derived suppressor cells in mesothelioma. Celecoxib influences MDSC function. BMC Cancer. 2010;10:464.

32. Yu Z, Tan Z, Lee BK, Tang J, Wu X, Cheung KW, Lo NT, Man K, Liu L, Chen Z. Antigen spreading-induced CD8+T cells confer protection against the lethal challenge of wild-type malignant mesothelioma by eliminating myeloidderived suppressor cells. Oncotarget. 2015;6(32):32426-38.

33. Minnema-Luiting J, Vroman $\mathrm{H}$, Aerts J, Cornelissen R. Heterogeneity in immune cell content in malignant pleural mesothelioma. Int J Mol Sci. 2018; 19(4):E1041.

34. Yap TA, Aerts JG, Popat S, Fennell DA. Novel insights into mesothelioma biology and implications for therapy. Nat Rev Cancer. 2017;17(8):475-88.

35. Conti I, Rollins BJ. CCL2 (monocyte chemoattractant protein-1) and cancer. Semin Cancer Biol. 2004;14(3):149-54.

36. Deshmane SL, Kremlev S, Amini S, Sawaya BE. Monocyte chemoattractant protein-1 (MCP-1): an overview. J Interf Cytokine Res. 2009;29(6):313-26.

37. Sica A, Schioppa T, Mantovani A, Allavena P. Tumour-associated macrophages are a distinct M2 polarised population promoting tumour progression: potential targets of anti-cancer therapy. Eur J Cancer. 2006; 42(6):717-27.

38. Balkwill F. Cancer and the chemokine network. Nat Rev Cancer. 2004;4(7): 540-50.

39. Huang B, Lei Z, Zhao J, Gong W, Liu J, Chen Z, Liu Y, Li D, Yuan Y, Zhang GM, et al. CCL2/CCR2 pathway mediates recruitment of myeloid suppressor cells to cancers. Cancer Lett. 2007;252(1):86-92.

40. Sica A, Porta C, Morlacchi S, Banfi S, Strauss L, Rimoldi M, Totaro MG, Riboldi E. Origin and functions of tumor-associated myeloid cells (TAMCs). Cancer Microenviron. 2012;5(2):133-49.

41. Cai Z, Chen Q, Chen J, Lu Y, Xiao G, Wu Z, Zhou Q, Zhang J. Monocyte chemotactic protein 1 promotes lung cancer-induced bone resorptive lesions in vivo. Neoplasia. 2009;11(3):228-36.

42. Hefler L, Tempfer C, Heinze G, Mayerhofer K, Breitenecker G, Leodolter S, Reinthaller A, Kainz C. Monocyte chemoattractant protein-1 serum levels in ovarian cancer patients. Br J Cancer. 1999;81(5):855-9.

43. Lebrecht A, Grimm C, Lantzsch T, Ludwig E, Hefler L, Ulbrich E, Koelbl H. Monocyte chemoattractant protein-1 serum levels in patients with breast cancer. Tumour Biol. 2004;25(1-2):14-7.

44. Lu X, Qian CN, Mu YG, Li NW, Li S, Zhang HB, Li SW, Wang FL, Guo X, Xiang YQ. Serum CCL2 and serum TNF-alpha--two new biomarkers predict bone invasion, post-treatment distant metastasis and poor overall survival in nasopharyngeal carcinoma. Eur J Cancer. 2011;47(3):339-46.

45. Lu Y, Chen Q, Corey E, Xie W, Fan J, Mizokami A, Zhang J. Activation of MCP-1/CCR2 axis promotes prostate cancer growth in bone. Clin Exp Metastasis. 2009;26(2):161-9.

46. Lubowicka E, Przylipiak A, Zajkowska M, Piskor BM, Malinowski P, Fiedorowicz W, Lawicki S. Plasma chemokine CCL2 and its receptor CCR2 concentrations as diagnostic biomarkers for breast Cancer patients. Biomed Res Int. 2018;2018:2124390.

47. Moogooei M, Shamaei M, Khorramdelazad H, Fattahpour S, Seyedmehdi SM, Moogooei M, Hassanshahi G, Kalantari Khandani B. The intricate expression of CC chemokines in glial tumors: evidence for involvement of CCL2 and CCL5 but not CCL11. Acta Med Iran. 2015;53(12):770-7.
48. Pan YW, Zhou ZG, Wang M, Dong JQ, Du KP, Li S, Liu YL, Lv PJ, Gao JB. Combination of IL-6, IL-10, and MCP-1 with traditional serum tumor markers in lung cancer diagnosis and prognosis. Genet Mol Res. 2016;15(4). https:// doi.org/10.4238/gmr15048949.

49. Sharma J, Gray KP, Harshman LC, Evan C, Nakabayashi M, Fichorova R, Rider J, Mucci L, Kantoff PW, Sweeney CJ. Elevated IL-8, TNF-alpha, and MCP-1 in men with metastatic prostate cancer starting androgen-deprivation therapy (ADT) are associated with shorter time to castration-resistance and overall survival. Prostate. 2014;74(8):820-8.

50. Wang WW, Ang SF, Kumar R, Heah C, Utama A, Tania NP, Li H, Tan SH, Poo D, Choo SP, et al. Identification of serum monocyte chemoattractant protein-1 and prolactin as potential tumor markers in hepatocellular carcinoma. PLoS One. 2013;8(7):e68904.

51. Wu J, Liu X, Wang Y. Predictive value of preoperative serum CCL2, CCL18, and VEGF for the patients with gastric cancer. BMC Clin Pathol. 2013;13:15.

52. Dehqanzada ZA, Storrer CE, Hueman MT, Foley RJ, Harris KA, Jama YH, Kao TC, Shriver CD, Ponniah S, Peoples GE. Correlations between serum monocyte chemotactic protein-1 levels, clinical prognostic factors, and HER2/neu vaccine-related immunity in breast cancer patients. Clin Cancer Res. 2006;12(2):478-86

53. Ding L, Li B, Zhao Y, Fu YF, Hu EL, Hu QG, Ni YH, Hou YY. Serum CCL2 and CCL3 as potential biomarkers for the diagnosis of oral squamous cell carcinoma. Tumour Biol. 2014;35(10):10539-46.

54. Farren MR, Mace TA, Geyer S, Mikhail S, Wu C, Ciombor K, Tahiri S, Ahn D, Noonan AM, Villalona-Calero $\mathrm{M}$, et al. Systemic immune activity predicts overall survival in treatment-naive patients with metastatic pancreatic Cancer. Clin Cancer Res. 2016;22(10):2565-74.

55. Koper OM, Kaminska J, Sawicki K, Reszec J, Rutkowski R, Jadeszko M, Mariak Z, Dymicka-Piekarska V, Kemona H. Cerebrospinal fluid and serum IL-8, CCL2, and ICAM-1 concentrations in astrocytic brain tumor patients. Ir J Med Sci. 2018;187(3):767-75.

56. Monti P, Leone BE, Marchesi F, Balzano G, Zerbi A, Scaltrini F, Pasquali C, Calori G, Pessi F, Sperti C, et al. The CC chemokine MCP-1/CCL2 in pancreatic cancer progression: regulation of expression and potential mechanisms of antimalignant activity. Cancer Res. 2003;63(21):7451-61.

57. Sullivan J, Gong Q, Hyslop T, Lavu H, Chipitsyna G, Yeo CJ, Arafat HA. Serum monocyte chemoattractant protein-1 in pancreatic cancer. J Oncol. 2011; 2011:518394.

58. Tas F, Karabulut S, Serilmez M, Karabulut M, Duranyildiz D. Elevated circulating monocyte chemoattractant protein 1 (MCP-1/CCL-2) level may be an unfavorable predictive factor to platinum- and taxane-based combination chemotherapy in patients with gastric cancer. Cancer Chemother Pharmacol. 2016;77(1):127-31.

59. Tonouchi H, Miki C, Tanaka K, Kusunoki M. Profile of monocyte chemoattractant protein-1 circulating levels in gastric cancer patients. Scand J Gastroenterol. 2002;37(7):830-3.

60. Tsaur I, Noack A, Makarevic J, Oppermann E, Waaga-Gasser AM, Gasser M, Borgmann H, Huesch T, Gust KM, Reiter M, et al. CCL2 chemokine as a potential biomarker for prostate Cancer: a pilot study. Cancer Res Treat. 2015;47(2):306-12.

61. Antonelli A, Rotondi M, Fallahi P, Ferrari SM, Paolicchi A, Romagnani P, Serio M, Ferrannini E. Increase of CXC chemokine CXCL10 and CC chemokine CCL2 serum levels in normal ageing. Cytokine. 2006;34(1-2):32-8.

62. Gerli R, Monti D, Bistoni O, Mazzone AM, Peri G, Cossarizza A, Di Gioacchino M, Cesarotti ME, Doni A, Mantovani A, et al. Chemokines, sTNF-Rs and SCD30 serum levels in healthy aged people and centenarians. Mech Ageing Dev. 2000;121(1-3):37-46.

63. Inadera H, Egashira K, Takemoto M, Ouchi Y, Matsushima K. Increase in circulating levels of monocyte chemoattractant protein-1 with aging. J Interf Cytokine Res. 1999;19(10):1179-82.

64. Gueugnon F, Leclerca S, Blanquart C, Sagan C, Cellerin L, Padieu M, Perigaud C, Scherpereel A, Gregoire M. Identification of novel markers for the diagnosis of malignant pleural mesothelioma. Am J Pathol. 2011;178(3):1033-42.

65. Saji H, Koike M, Yamori T, Saji S, Seiki M, Matsushima K, Toi M. Significant correlation of monocyte chemoattractant protein-1 expression with neovascularization and progression of breast carcinoma. Cancer. 2001:92(5): 1085-91.

66. Ueno T, Toi M, Saji H, Muta M, Bando H, Kuroi K, Koike M, Inadera H, Matsushima K. Significance of macrophage chemoattractant protein-1 in macrophage recruitment, angiogenesis, and survival in human breast cancer. Clin Cancer Res. 2000;6(8):3282-9. 
67. Valkovic T, Lucin K, Krstulja M, Dobi-Babic R, Jonjic N. Expression of monocyte chemotactic protein-1 in human invasive ductal breast cancer. Pathol Res Pract. 1998;194(5):335-40.

68. Wang J, Zhuang ZG, Xu SF, He Q, Shao YG, Ji M, Yang L, Bao W. Expression of CCL2 is significantly different in five breast cancer genotypes and predicts patient outcome. Int J Clin Exp Med. 2015:8(9):15684-91.

69. Lu Y, Cai Z, Galson DL, Xiao G, Liu Y, George DE, Melhem MF, Yao Z, Zhang J. Monocyte chemotactic protein-1 (MCP-1) acts as a paracrine and autocrine factor for prostate cancer growth and invasion. Prostate. 2006; 66(12):1311-8.

70. Shirotake S, Miyajima A, Kosaka T, Tanaka N, Kikuchi E, Mikami S, Okada Y, Oya M. Regulation of monocyte chemoattractant protein-1 through angiotensin II type 1 receptor in prostate cancer. Am J Pathol. 2012;180(3): 1008-16.

71. Tao LL, Shi SJ, Chen LB, Huang GC. Expression of monocyte chemotactic protein-1/CCL2 in gastric cancer and its relationship with tumor hypoxia. World J Gastroenterol. 2014;20(15):4421-7.

72. Bailey C, Negus R, Morris A, Ziprin P, Goldin R, Allavena P, Peck D, Darzi A. Chemokine expression is associated with the accumulation of tumour associated macrophages (TAMs) and progression in human colorectal cancer. Clin Exp Metastasis. 2007:24(2):121-30.

73. Yoshidome H, Kohno H, Shida T, Kimura F, Shimizu H, Ohtsuka M, Nakatani Y, Miyazaki M. Significance of monocyte chemoattractant protein-1 in angiogenesis and survival in colorectal liver metastases. Int J Oncol. 2009; 34(4):923-30.

74. Ohta M, Kitadai Y, Tanaka S, Yoshihara M, Yasui W, Mukaida N, Haruma K, Chayama K. Monocyte chemoattractant protein-1 expression correlates with macrophage infiltration and tumor vascularity in human esophageal squamous cell carcinomas. Int J Cancer. 2002;102(3):220-4.

75. Ji WT, Chen HR, Lin CH, Lee JW, Lee CC. Monocyte chemotactic protein 1 (MCP-1) modulates pro-survival signaling to promote progression of head and neck squamous cell carcinoma. PLoS One. 2014;9(2):e88952. https://doi. org/10.1371/journal.pone.0088952. eCollection 2014.

76. Watanabe H, Miki C, Okugawa Y, Toiyama Y, Inoue Y, Kusunoki M. Decreased expression of monocyte chemoattractant protein-1 predicts poor prognosis following curative resection of colorectal cancer. Dis Colon Rectum. 2008;51(12):1800-5.

77. Chew V, Tow C, Teo M, Wong HL, Chan J, Gehring A, Loh M, Bolze A, Quek R, Lee VK, et al. Inflammatory tumour microenvironment is associated with superior survival in hepatocellular carcinoma patients. J Hepatol. 2010;52(3):370-9.

78. Zhang XW, Qin X, Qin CY, Yin YL, Chen Y, Zhu HL. Expression of monocyte chemoattractant protein-1 and CC chemokine receptor 2 in non-small cell lung cancer and its significance. Cancer Immunol Immunother. 2013;62(3):563-70.

79. Bonecchi R, Mollica Poeta V, Capucetti A, Massara M. Chemokines and chemokine receptors: new targets for cancer immunotherapy. Front Immunol. 2019;10:379.

80. Bonelli S, Geeraerts X, Bolli E, Keirsse J, Kiss M, Pombo Antunes AR, Van Damme H, De Vlaminck K, Movahedi K, Laoui D, et al. Beyond the M-CSF receptor - novel therapeutic targets in tumor-associated macrophages. FEBS J. 2018;285(4):777-87.

81. Chun E, Lavoie S, Michaud M, Gallini CA, Kim J, Soucy G, Odze R, Glickman JN, Garrett WS. CCL2 promotes colorectal carcinogenesis by enhancing Polymorphonuclear myeloid-derived suppressor cell population and function. Cell Rep. 2015;12(2):244-57.

82. Draghiciu O, Lubbers J, Nijman HW, Daemen T. Myeloid derived suppressor cells-an overview of combat strategies to increase immunotherapy efficacy. Oncoimmunology. 2015;4(1):e954829.

83. Draghiciu O, Nijman HW, Hoogeboom BN, Meijerhof T, Daemen T. Sunitinib depletes myeloid-derived suppressor cells and synergizes with a cancer vaccine to enhance antigen-specific immune responses and tumor eradication. Oncoimmunology. 2015;4(3):e989764.

84. Lesokhin AM, Hohl TM, Kitano S, Cortez C, Hirschhorn-Cymerman D, Avogadri F, Rizzuto GA, Lazarus JJ, Pamer EG, Houghton AN, et al. Monocytic CCR2(+) myeloid-derived suppressor cells promote immune escape by limiting activated CD8 T-cell infiltration into the tumor microenvironment. Cancer Res. 2012;72(4):876-86.

85. Nywening TM, Belt BA, Cullinan DR, Panni RZ, Han BJ, Sanford DE, Jacobs RC, Ye J, Patel AA, Gillanders WE, et al. Targeting both tumour-associated CXCR2(+) neutrophils and CCR2(+) macrophages disrupts myeloid recruitment and improves chemotherapeutic responses in pancreatic ductal adenocarcinoma. Gut. 2018;67(6):1112-23.
86. Du L, Che Z, Wang-Gillam A. Promising therapeutics of gastrointestinal cancers in clinical trials. J Gastrointest Oncol. 2017;8(3):524-33.

87. Elliott LA, Doherty GA, Sheahan K, Ryan EJ. Human tumor-infiltrating myeloid cells: phenotypic and functional diversity. Front Immunol. 2017;8:86.

88. Fleming V, Hu X, Weber R, Nagibin V, Groth C, Altevogt P, Utikal J, Umansky $V$. Targeting myeloid-derived suppressor cells to bypass tumor-induced immunosuppression. Front Immunol. 2018;9:398.

89. Lim SY, Yuzhalin AE, Gordon-Weeks AN, Muschel RJ. Targeting the CCL2CCR2 signaling axis in cancer metastasis. Oncotarget. 2016;7(19):28697-710.

90. Majety M, Runza V, Lehmann C, Hoves S, Ries CH. A drug development perspective on targeting tumor-associated myeloid cells. FEBS J. 2018;285(4): $763-76$.

91. Nywening TM, Wang-Gillam A, Sanford DE, Belt BA, Panni RZ, Cusworth BM, Toriola AT, Nieman RK, Worley LA, Yano M, et al. Targeting tumourassociated macrophages with CCR2 inhibition in combination with FOLFIRINOX in patients with borderline resectable and locally advanced pancreatic cancer: a single-Centre, open-label, dose-finding, nonrandomised, phase 1b trial. Lancet Oncol. 2016;17(5):651-62.

92. Poh AR, Ernst M. Targeting macrophages in Cancer: from bench to bedside. Front Oncol. 2018;8:49.

93. Ries CH, Cannarile MA, Hoves S, Benz J, Wartha K, Runza V, Rey-Giraud F, Pradel LP, Feuerhake F, Klaman I, et al. Targeting tumor-associated macrophages with anti-CSF-1R antibody reveals a strategy for cancer therapy. Cancer Cell. 2014;25(6):846-59.

94. Ruffell B, Coussens LM. Macrophages and therapeutic resistance in cancer. Cancer Cell. 2015;27(4):462-72

95. Lu J, Zhong H, Chu T, Zhang X, Li R, Sun J, Zhong R, Yang Y, Alam MS, Lou $Y$, et al. Role of anlotinib-induced CCL2 decrease in anti-angiogenesis and response prediction for nonsmall cell lung cancer therapy. Eur Respir J. 2019;53(3).

\section{Publisher's Note}

Springer Nature remains neutral with regard to jurisdictional claims in published maps and institutional affiliations.

\section{Ready to submit your research? Choose BMC and benefit from:}

- fast, convenient online submission

- thorough peer review by experienced researchers in your field

- rapid publication on acceptance

- support for research data, including large and complex data types

- gold Open Access which fosters wider collaboration and increased citations

- maximum visibility for your research: over $100 \mathrm{M}$ website views per year

At $\mathrm{BMC}$, research is always in progress.

Learn more biomedcentral.com/submissions 